\title{
Mongolia's efforts toward peace and stability in North East Asia
}

\author{
By P.Ochirbat (Mongolia)
}

\begin{abstract}
$\mathrm{M}$ y I extend a warm welcome and greetings to all the participants of IPPNW/North Asia regional meeting. It is a great pleasure to wish success to your meeting, which is making a constructive contribution to seriously considering the establishment of a Nuclear-Weapon-Free Zone in North-East Asia (NEA-NWFZ) . I hope you will have ample opportunity to exchange visions and views on such a timely, demanding and vital topic not only for peace and security in our North-East Asian region but for the whole world. I also hope that the meeting would outline specific ways and means to promote NEA-NWFZ in the nearest future, individually or collectively, and, by so doing, would practically contribute to the establishment of such a zone.
\end{abstract}

\section{Challenges and risks}

Since there are a number of countries in this region that are mastering nuclear technology and are increasingly developing nuclear power generation and nuclear energy production, it is vitally important to make North-East Asia a region free from nuclear weapons. Otherwise if a State chooses to go nuclear, then others would surely follow suit which, in turn, would ignite an arms race and impede confidence-building and cooperation. Ultimately, the most dynamically developing region in the world could become a hotspot of controversies or conflicts.

Expanded discussion and regional dialogue on the establishment of a NWFZ in this region would increase awareness and understanding of the subject matter among the countries of the region, promote serious search for non-nuclear security architecture and infrastructure in the future, acquisition of security assurances from nuclear-weapon States, 
negotiation of a verification machinery and would gradually lead to the establishment of a regional security structure.

Judging from present day regional politics it might seem premature to suggest formal discussion of all these issues at the govermmental level. Therefore, non-governmental organizations (NGOs), academia and research institutions should take a lead in launching exchange of views or proposing constructive and pragmatic proposals or specific initiatives which, logically, could have a positive effect on official govemmental policies. There are a great variety of initiatives originated from NGOs which won the hearts and minds of the international community, incredibly positive examples of which are the initiatives of the International Physicians for the Prevention of Nuclear War (IPPNW) and of the movement to ban anti-personnel landmines. There are many other examples when such initiatives like on human rights and environmental protection and other humanitarian dimensions have had instrumental impact on the human development. I am positive that your meeting will produce very specific initiatives or pragmatic solutions on the issues on your agenda.

\section{New foreign policy}

During the cold war Mongolia was member of socialist commonwealth and part of Soviet Union alliance. In foreign affairs, 90 percent was attributed to the member-countries of the then existing socialist world. Although Mongolia established and maintained diplomatic relations with North-East Asian countries, trade, economic, cultural or humanitarian ties were almost non-existent.

After the end of the cold war Mongolia adopted its new national security strategy and independent foreign policy. Unlike in the past, when Mongolia was driven by the common interests of the socialist countries (in the final analysis of Soviet Union's interests), new national security strategy and foreign policy are now based on genuine national interests and universal human values. Similarly, new policies restructured the very nature of Mongolia's foreign affairs making it multi-pillar and seeking to acquire as many friends and partners as possible.

By geographic definition Mongolia's foreign policy sets first priority to the relationship with Russia and China. We now accept a strategy of building relations with industrially developed countries of the Fast and West, among them especially with the North-East Asian States. Within 
this new strategy we introduced a "third neighbor" notion which envisages advanced development of relationship with the North-East Asian States.

\section{North-East Asia policy}

At the beginning of the 1990's, while defining the foreign policy priorities, we came across a dilemma whether to choose Central Asia or North East Asia region as a priority region. At that point and time, taking account of Mongolia's historical background, its geo-political location, economic, trade and investment environment and needs, as well as available future opportunities, we chose the latter. On their part, North-East Asian fellow countries welcomed our new policy change. As a result of our policies, today Mongolia is a party to regional multilateral and multidimensional cooperation processes.

Mongolia has long-standing expectations to join the on-going regional integration processes. More specifically, Mongolia pins strong interest to have access to the dynamically developing regional markets and contribute its natural resources, as well as to link North-East Asia with no less natural resource-rich Central Asia and become a bridge connecting Euro-Asian markets by landmass. We believe that there are great potentials and possibilities to build developmental cooperation amongst natural resource-rich Russia and Mongolia, human resourcesrich China, financially and technologically developed Japan and the Republic of Korea that logically supplement each other. Moreover, we think that when DPRK joins the integration process, it will speed up further regional development and prosperity. Today North-East Asian economies make up 80 percent of Mongolia's overall foreign direct investment and foreign trade. With increased and deepened integration these figures will surely rise.

\section{Regional security arrangement}

Should regional countries build cooperation and boost integration among themselves, there is a challenging task to build confidence, peacefully resolve disputes or differences and develop a regional security cooperation architecture. Fortunately, bilateral, trilateral or multilateral cooperation dialogues on official or informal levels are underway. To name a few multilateral intergovernmental fora - Asian Cooperation Dialogue, ASEAN Regional Forum, APEC, East Asia Micro Davos, 
Six-Party Talks, Shangri-La Meeting etc, . The North-East Asian countries discuss multilateral cooperation efforts, possibilities of developing regional arrangements, as well as the ways and means of establishing regional security cooperation machinery. There are ideas to make the Six-Party Talks into a future bedrock of the North-East Asian security cooperation mechanism. There are also proposals to the effect that if and when a NWFZ is established, that could enable the emergence of a comprehensive solution, since NWFZ mechanism would link issue of nuclear war prevention with the issues of security cooperation mechanism and acquisition of security assurances from nuclear-weapon States.

\section{Mongolia's regional cooperation proposals}

Following its North-East Asia policy, Mongolia seeks to make its own contribution to the regional multilateral cooperation efforts. Namely, with a view to developing an efficient cooperation dialogue mechanism in the North-East Asia region, Mongolia proposed in 2000 to set up a permanent intergovernmental regional security dialogue form. In 2005 Mongolia hosted a Regional workshop on "ASEAN Regional Forum Member-Countries' Changing Security Strategies" with participants from 21 regional States. Also Mongolia hosted Defense University Directors' Meeting. This month Mongolia hosted the OSCE and Asian Partners for Cooperation Consultative Meeting. Similarly, Mongolia expressed on a number of various occasions its willingness, if there is a need, to promote the Six-Party Talks.

Mongolia's two neighbors' friendly bilateral relationship is crucially important for security and stability in North-East Asia. The UN General Assembly declared on a number of occasions that Mongolia is successfully developing a balanced relationship with Russia and China which in its tum has a very positive bearing on regional stability.

\section{Non-nuclear-weapon status}

With a view to ensuring its national security primarily by political and diplomatic means and contributing to regional stability, in 1992 Mongolia declared its territory a NWFZ. This nuclear-weapon-free status is recognized intemationally. Mongolia's proposal demonstrates excellent possibility for nearly a dozen single States to acquire a NWFZ status. 
Its strategic goal is to rule out the use of its territory against any other State, non-participation in the disputes that may arise among the great powers and pursue a policy of neutrality with regard to such disputes that do not directly affect its vital interests.

With respect to Mongolia's experience in promoting the establishment of North-East Asian NWFZ, I wish to make one point. Pending the establishment of such a zone, why not the countries in the region that are under the nuclear umbrella think of abandoning it, declaring themselves single- State NWFZs and thus acquiring the needed security assurances from nuclear-weapon States. On the other hand, those States which have no nuclear umbrella nor alliance relationship could, also, unilaterally declare themselves single-State NWFZ and acquire conventional and nuclear security assurances from the nuclearweapon States. 